\title{
Hetesi Erzsébet
}

Szegedi Tudományegyetem Gazdaságtudományi Kar

ORCID:0000-0001-8518-407X

\section{Juhász Zoltán}

Szegedi Tudományegyetem Általános Orvostudományi Kar

ORCID:0000-0002-8761-2389

\section{Hitelesség és bizonytalanság a kommunilkációban a COVID- 19 idején}

\begin{abstract}
Absztrakt
Tanulmányunkban arra keressük a választ, hogy a magyar kormányzat járványkezelési intézkedései a pandémia első szakaszában hogyan befolyásolták az online platformokon észlelt kommunikációs aktivitást. Primer kutatásunk célja a járványkezeléssel kapcsolatos kommunikáció lakossági megítélésének felmérése. Kutatásunkban a maszkviseléssel és a kórházi ágyak gyors felszabadításával kapcsolatos kommunikációt vizsgáltuk netnográfiai módszerrel, 5 online fórum összesen 2000 kommentjének elemzésével. A fórumok kommentjei alapján az online közösségben nagyon szélsőséges és eltérő vélemények (szkepticizmus, megbotránkozás, vádaskodás, elfogadás) alakultak ki az egészségügyi kommunikáció pontosságáról és megbízhatóságáról. Kutatásunk eredményei azt jelzik, hogy a COVID-19 idején mind a politikai, mind az egészségügyi kommunikáció megosztotta a magyar lakosság véleményét az online platformokon.
\end{abstract}

Kulcsszavak: pandémia, politikai és egészségügyi kommunikáció, bizalmatlanság, netnográfia

\begin{abstract}
Credibility and uncertainty in communication during COVID-19

In our study, we seek the answer to how Hungarian government epidemic management measures in the first phases of the pandemic affected the communication activity observed on online platforms. The aim of our primary research was to examine what marked opinions were expressed in the assessment of communication related to epidemic management. Among the measures in the first phase, we examined communication related to mask wearing and rapid release of hospital beds using a netnographic method, analyzing a total of 2,ooo comments from 5 online forums. Based on the forum comments, very extreme and divergent opinions (scepticism, indignation, accusation, acceptance) about the accuracy and reliability of health communication emerged in the online community. The results of our research indicate that during COVOD-19, both political and health communication divided the opinions of the Hungarian population on online platforms.
\end{abstract}

Keywords: pandemic, political and health communication, mediatization, communication distrust, netnography

\section{Bevezetés}

A 2019. év végén Kínából induló, majd pandémiává váló koronavírus járvány az utóbbi évszázad talán legnagyobb kihívása elé állítja a világ országait. Egy ilyen gyorsan terjedő, ismeretlen vírus okozta pandémia idején a világon mindenütt szükség van a politika, a kormányok és az 
egészségügyi szakemberek együttmúködésére a védekezésben, és különösen az intézkedések transzparens, az állampolgárok számára átlátható, megnyugtató kommunikálására. Ahogy a kommunikáció jelentősége a COVID járványban világszerte megnőtt, úgy Magyarországon is kiemelt szerepet kapott a lakosság tájékoztatása a járványügyi intézkedésekről, és ennek fő csatornái a tömegkommunikációs eszközök (TV, rádió, online sajtó) lettek, amelyek igyekeztek felhívni a lakosságot az intézményekkel és hatóságokkal való együttmüködésre. Ahhoz, hogy ez az együttmúködés sikeres legyen, követelmény a kommunikáció során a hitelesség, a megbízhatóság, az egyértelműség/közérthetőség, és főként a bizalom.

Magyarországon a COVID kapcsán sajátos, erősen centralizált, egycsatornás kommunikáció a jellemző a mai napig, így az egészségügyi kommunikáció is csak ennek tükrében vizsgálható. Ott, ahol az egészségügyi intézmények önállóan nem adhattak ki adatokat a fertőzöttek, kezeltek és elhunytak számáról, ahol csak a hivatalos csatornákon és csak területi bontásban értesülhettek az állampolgárok a COVID országos járványügyi adatairól, ahol kórházi vezetôket bocsájtottak el, ha megszegték a központi utasításokat, és ahol katonai parancsnokokat nevezték ki az egészségügyi és szociális intézményekbe, ott számos kérdésben bizonytalanság alakult ki az intézményi kommunikációban és a lakosság körében is.

Tanulmányunk első részében a politikai és egészségügyi kommunikációt érintő szakirodalom rövid áttekintése után bemutatjuk, hogy milyen sajátosságokkal írhatók le a kommunikáció különböző típusai, azok átfedései milyen anomáliákat eredményeznek, és a pandémia idején ennek milyen következményei lehetnek. Napjainkban olyan új jelenségekkel találkozunk, mint a tudományok korrumpálódása, a politikai és egészségügyi kommunikáció mediatizációja, amelyek témánk és kutatásunk szempontjából jelentősek, ezért röviden e kérdésekre is kitérünk.

Kvalitatív vizsgálatunk bemutatása során ismertetjük kutatási céljainkat, az alkalmazott módszert és az eredményeket. Az eredmények alapján megpróbáljuk felvázolni, hogy a kommunikációk hogyan befolyásolták a közvéleményt, és a krízist követően vajon milyen változások várhatók.

\section{A téma elméleti háttere}

Mivel tanulmányunk célja a kormányzati (politikai) és egészségügyi kommunikáció hatékonyságának vizsgálata a lakosság tájékoztatásában a COVID-19 világjárvány idején, ezért az elméleti részben a politikai és az egészségügyi kommunikáció jellemzőit is érintjük.

A politikai és egészségügyi kommunikáció tartalmának értelmezése maga is bizonytalanságforrás az állampolgárok számára, és ez fokozódott a COVID-19 idején. A járvány idején a kommunikáció színtere szinte kizárólag a média volt. A politikusok és az egészségügyi szakemberek a médián keresztül kommunikáltak a polgárokkal, a polgárok pedig elsősorban a közösségi médiában kapott információkra reagáltak. Ezért a szakirodalom áttekintésében röviden megvitatjuk a politikai és egészségügyi kommunikáció mediatizálódását és annak következményeit is.

\subsection{Politikai kommunikáció}

A politika definiálása nem célja tanulmányunknak, többek között azért sem, mert annyi meghatározással találkozunk, ahányan írnak róla. Azt azonban fontosnak tartjuk megjegyezni, hogy a politika tartalma ma már nagyon más, mint amit Arisztotelész (1994), vagy John Locke (1986) gondoltak a politika természetéről. Különösen sok változáson ment át az elmúlt évtizedekben a róla való vélekedés, de abban egyetérthetünk, hogy a politika érdek által meghatározott, célokat követő és akaratlagos tevékenység, amely a hatalom megszerzésére és megtartására irányul (Bihari 2013). A célok közvetítése a hatalomhoz segítők számára a kommunikáció segítségével történik.

Mazzoleni (2002) magyarul is megjelent könyvében azt mondja, hogy a politikai kommunikáció demokráciákban létezik, de oly módon, hogy közben a hatalom forrásává, a politikai versengés és a politikai erők közötti harc színterévé vált. Merkovity (2008) számos tanulmány és érdekes példa alapján úgy gondolja, hogy a politikai kommunikációt olyan gyüjtőfogalomként kell használnunk, amely magában foglalja a politikai nyelvet és beszédet, a politikai üzenetet valamint a tartalmat, és szélesebb értelemben tartalmazza a kommunikációs csatornákat is 
(Merkovity 2008). A politikai nyelv két fontos eleme a meggyőzés és a manipuláció. E két kategória szakirodalma nagyon gazdag (Aronson 1972, Breton 2000, Komár 2019). A meggyőzés és a manipuláció egyaránt a befolyásolás kategóriájába tartozik, ám az egyik tisztességes szándék, a másik nem az. (A meggyőzés az, amikor az észérvek, indokok a saját véleményétól eltérő vélemény indokolása győzi meg a befogadót, a manipuláció pedig az, amikor a befogadó nincs tisztában azzal, hogy egy másik véleményt akarnak vele elfogadtatni, és ő feltétel nélkül veszi át azt).

A politikai kommunikáció önmagában is nehezen értelmezhető, mert vannak alapszabályai.

Grice (1997) szerint a sikeres kommunikáció érdekében a közlőnek közlendője megfogalmazása során a tárgyra kell koncentrálnia. Nem szerencsés, ha a szükségesnél több vagy kevesebb szót használ, kerülnie kell a homályos jelentésű, kétértelmű szavakat, és nem ajánlatos olyat mondania, aminek igazságáról nincs meggyőződve. A politikai kommunikáció esetében a Grice-i maximák fordított alkalmazása hatékony. „A politikai kommunikációt a Carl Schmitt-i logika hatja át... „légy irreleváns!”. „a szükségesnél mondj többet vagy kevesebbet!”, „használj homályos, kétértelmű szavakat!”, „ne mondj olyat, amiről tudod, hogy igaz” (Schmitt 1935, idézi Csepeli 2010).

Jóval korábban V. Pareto is azt tanácsolta a politikusoknak: „Beszélj az örök igazságról, de cselekedj úgy, mintha egyáltalán nem létezne. Hasznos, ha az emberek azt hiszik, hogy az istenek harcolnak helyettük" (Szczepanski 1973: 327).

A mai társadalmakban a politikai kommunikáció alapvetően a tömegmédiában jelenik meg, ami új típusú nyelvi manipulációk létrehozásához vezet. Rozina és Karapetjana (2009) tanulmányukban két (Cheney és Obama) interjút elemeznek pragmatikus szempontból, és ezek alapján megpróbálják megvizsgálni a manőverezési technikákat és szakaszokat. Arra hívják fel a figyelmet, hogy a manőverezés homályos területeit azért kell körülhatárolni és tisztázni, mert hatással vannak annak megértésére, hogy a politikai beszédek hogyan szólítják meg a befogadókat (olvasókat, hallgatókat), és ezek a befogadók hogyan tudnák kideríteni a manőverezés mögött álló mozgatórugókat.

Mazzetti (2020) cikkében a COVID-19 világjárvány alatti politikai kommunikáció aspektusait tárgyalja. A cikk példákkal és a szakirodalom elemzésével azt kívánja bemutatni, hogy a politikai kommunikációt néha olyan rejtett motivációk vezérlik, amelyek egyes politikai képviselők hatalmi céljait szolgálják, nem pedig a közjót.

„A járvány kezdete óta minket, olasz állampolgárokat (és valószínúleg nem csak minket, olaszokat) a politikusok és tudományos tanácsadóik felelőtlen gyermekekként kezeltek. Úgy tünik, még a legtechnikásabb kommunikáció is koherens stratégiát követett, amelynek célja elsősorban a lakosság megfélemlítése volt, hogy otthon tartsa őket” (Mazzetti 2020: 6).

Ami a politikai kommunikáció tartalmát illeti, Magyarországon a világjárvány idején a kormány az egészségügyi szakemberekre hivatkozva igyekszik erőt, bizalmat és sikert közvetíteni, miközben nemcsak a szakértők, hanem a polgárok véleményét is megosztja. A COVID-19 idején látványosan megnyilvánult a kormányzati és az ellenzéki politikai kommunikáció érdekérvényesítésre való törekvése. Nevezetesen az, hogy az ellenzék is az érdekeit követte: a néha még rendkívül racionálisnak tűnő érvekből is látható volt, hogy a cél a következő választások megnyerése.

Kutatási kérdésünk a kormányzati információkkal kapcsolatban pontosan az, hogy a politikai kommunikáció következetlensége hogyan befolyásolja a polgárok véleményét?

\section{A politika mediatizálása}

Walter Lippmann (2007) még a húszas években írta meg, hogy a politika a média által teremtett pszeudovalóság. Mazzoleni és Schulz (2002) a mediatizált politikát olyan folyamatként értelmezik, amely a modern tömegmédia fejlődésének problémás kísérőjelenségeit vagy következményeit jelöli. Strömbäck (2008) szerint a mediatizált politika négy szintjét lehet megkülönböztetni az információforrás helye, a politika és a média kölcsönös függősége, valamint a tartalmat és a szereplőket befolyásoló logika alapján (1. táblázat). 
Legfontosabb

információforrás:

tapasztalatok,

interperszonális

kommunikáció

A média független a politikai intézményektől

A médiatartalmakat a

politikai logika befolyásolja

A politikai szereplőket a

politikai logika befolyásolja
1. táblázat: A mediatizált politika szintjei

Legfontosabb

információforrás: média

A média nem független a politikai intézményektől

A médiatartalmakat a médialogika befolyásolja

A politikai szereplőket a médialogika befolyásolja

Forrás: Strömbäck (2008)

Látható, hogy a média súlyának növekedésével új szerepek alakulnak ki, ez pedig a pandémia idején olyan méreteket öltött, amelyek az információkban való eligazodást rendkívüli módon nehezítik.

\subsection{Egészségügyi kommunikáció}

A tradicionális orvos-beteg kommunikáció helyszíne és módja sokat változott az elmúlt évtizedekben. Az Egészségügyi Világszervezet szerint az egészségügyi kommunikáció hatékonyságát a következő jellemzők határozzák meg: pontosság, elérhetőség, egyensúly, következetesség, kulturális kompetencia, ismétlés, időszerűség és érthetőség (WHO 2017).

A COVID-19 esetében a betegség megelőzésére és kezelésére vonatkozó tudományos ismeretek egyre inkább növekednek. Az új ismeretek kommunikációja kihívás elé állítja a tudományos szakma és a kormányzati politika képviselőit. A járványügyi védekezésben, a megbetegedések és halálozások csökkentésében, a gazdasági visszaesés mérséklésében a legnagyobb szerep az egészségügyi ellátórendszerekre hárul. A gyors és hatékony egészségügyi ellátás megszervezésében, a lakosság felkészítésében kiemelt helyet kap a kommunikáció. A lakosságra és az egészségügyi szakemberekre irányuló kommunikáció célja a koronavírus járványban elsősorban a biztonságérzet erősítése, a tájékozottság növelése, de fontos szerepet kap a szolidaritás is. A pandémia alatt megszerzett tudást és eszközöket olyan módon kell népszerüsíteni és bemutatni, hogy a népegészségügyi célkitűzések ne csupán szabályozással és végrehajtással, hanem közösségi elköteleződés és támogatás által is teljesüljenek.

A hatékony egészségügyi kommunikációnak nem célja a befogadók túlterhelése nehezen értelmezhető információkkal, hanem sokkal inkább a rendelkezésre álló információ felhasználásával az egyéni hatékonyság fokozása.

A jövőben a COVID-19-hez hasonló, különösen veszélyes járványok eredményes kezeléséhez és megelőzéséhez világos, empatikus, cselekvésre ösztönző üzeneteket tartalmazó, az adott célcsoport igényeihez igazodó kommunikáció szükséges (Hanafiah et al. 2021).

A járványügyi intézkedések az egészségügyben használatos kommunikációs csatornák átalakulását hozták magukkal. A járvány terjedését lassító intézkedések egyik fontos eleme a személyes kontaktusok csökkentése, a személyes orvos-beteg találkozások minimalizálása, a távkonzultáció bevezetése. A jelenlegi helyzetben a kommunikáció egyik fő színtere az Internet lett, és egyre inkább felértékelődik a közösségi média szerepe az egészségügyi információ áramoltatásában, a közösségi kapcsolattartásban. A közösségi média kiváló lehetőséget biztosít a népegészségügyi tartalmú információk gyors terjesztéséhez, hozzájárul a populáció funkcionális egészség-értésének javulásához. A közösségi média 2004-es megjelenése óta egyre szélesebb körben használják egészségügyi témájú kommunikációra (Smailhodzic et al. 2016). 
Bár magyar viszonyok között az Instagram sokkal kisebb hatással van jelen, mint a Facebook, és legfeljebb az influencerek közvetítenek releváns egészségügyi információkat - meglehetősen ellentmondásosan, leginkább szkeptikusan - a nemzetközi szakirodalmak felhívják a figyelmet az Instagram jelentőségére az egészségügyi kommunikációban. Az Instagram hatékony eszköz lehet az egészségügyi szervezetek számára az üzenetek közvetítésében a válságkommunikáció során. A pontos információ szolgáltatásával, a felhasználók hiteles forráshoz irányításával segítséget jelenthetnek, szerepet játszhatnak a hamis/téves információk elleni küzdelemben. Az Instagramon COVID-19 járvány alatt a népegészségügyi intézmények közül az USA-ban a CDC és a WHO voltak a legaktívabbak az összes értékelt szervezet közül a posztok számát, eléréseket és elkötelezettség mutatóit tekintve. Különösen nagymértékű online felhasználói aktivitás volt megfigyelhető a hírességekről szóló, magyarázatokat és infografikákat tartalmazó bejegyzéseknél (Malik et al. 2021).

Egy pakisztáni tanulmányban a szerzők azt találták, hogy a közösségi médiának nincs jelentős és közvetlen hatása a megelőző magatartásra, míg a tudatosság és az információcsere közvetlenül befolyásolta a megelőző magatartást. Ugyanakkor eredményeik azt is jelezték, hogy a megelőző magatartást befolyásolja az egyének iskolai végzettsége, neme, életkora és jövedelme (Nazir et al. 2020). Az online platformok mellett a járványban legsérülékenyebb, 65 éven felüli, internetet kevésbé használó populáció eléréséhez a hagyományos tömegkommunikációs eszközök használata is nélkülözhetetlen.

\section{Az egészségügy mediatizálása}

Bár a politika mediatizálása régóta kutatási téma, az egészségügyi kommunikáció mediatizálása új jelenség, ugyanis a járvány idején az egészségügyi kommunikáció csatornái jelentősen megváltoztak. Az egészségügyi ágazat korábban nem részesült olyan intenzív médiafigyelemben, mint a politika. Bár a média egészségkommunikációra gyakorolt hatásáról találhatunk tanulmányokat (Wright et al. 2013; Christensen 2016), a mediatizálódást a COVID-19 során tapasztaltuk (Athique 2020). A COVID-19 során egyrészt az egészségügyi szakemberek nagyon gyakran jelentek meg a médiában, másrészt a közösségi média jelentős szerepet kapott a tájékoztatásban. Az igazi kérdés azonban az, hogy mi vezethet oda, hogy egy olyan fontos - emberéletekért felelős - diszciplína, mint az orvostudomány, hiteltelenné váljék a politika hatására. (Bár a szakirodalmakban már korábban megjelentek írások, amelyek az egészségügy új posztmodern paradigmájáról szólnak, ahol a hatalom az orvosokról a betegekre helyeződik át, ahol ennek következményeként a tudomány legitimitása megkérdőjelezhető, és a szakértelem újradefiniálódik (Kata 2012), mi itt nem erre gondolunk. Nem arra, hogy az internet hogy ad lehetőséget az információk cseréjére a páciensek, vagy aktivisták között, és hogy képes átvenni a hatalmat a tudomány állításai felett, hanem kifejezetten arra, hogy a politika nyomására miként képes korrumpálódni egy diszciplína.)

A fizikai távolságtartás, a karantén és a gazdasági korlátok szorongást keltenek a lakosságban, és növelik az információgyüjtés- és ellenőrzés, a szakértői vélemények iránti igényt. Portugáliában a COVID-19 kommunikációt is az Egészségügyi Minisztérium központosította. Videókat tettek közzé a közösségi médiában, és egy független weboldalt indítottak videókkal, infografikákkal, füzetekkel, kézikönyvekkel. Emellett egy hivatalos honlapot is létrehoztak, amely a végrehajtott kormányzati intézkedéseket, a jogi tudnivalókat ismertette. E kommunikációs csatornák múködése ellenére az üzenetek nem jutottak el a teljes lakossághoz, és nem sikerült megragadniuk a figyelmet és befolyásolniuk a viselkedést. A lakosság megfelelő egészségmagatartásának kialakítását erőteljes egészségügyi kommunikációs stratégiával kell támogatni. A kommunikációs stratégiának egyértelmú információkat kell tartalmaznia a COVID-19 megelőzéséről és kezeléséről, az egészségügyi és szociális támogató szolgáltatásokhoz való hozzáférésről, a kommunikációs csatornák szélesebb körének felhasználásával (Leao et al. 2021).

Egy az Egyesült Államokban végezett felmérés eredményei alapján a lakosság túlnyomó többsége (69\%) előnyben részesítette az egészségügyi és tudományos alapokon nyugvó járványkezelést és vezetést (pl. a Betegségmegelőzési és Járványügyi Központ, Nemzeti Egészségügyi Intézet irányításával). A válaszadók mindössze 14\%-a gondolta úgy, hogy a járványkezelés folyamatát a politikának (USA Elnöke, Kongresszus) kellene irányítania. A reaktív, nyílt és tiszteletteljes kommunikáció javithatja a népegészségügyi szereplők együttműködését és biztonságot (McFadden et al. 2020). 
Indiai szerzők a kockázatkommunikációt funkcionális és emocionális összetevőkre bontották. A funkcionális összetevőhöz az időszerüség és az átláthatóság, az emocionálishoz pedig az empátia és bizalom tartoznak. Megállapították, hogy az elkötelezettség kulcsfontosságú a felhatalmazás és részvétel szempontjából, amelyek elősegíthetik a nyilvánosság és kormányzat közötti hatékonyabb együttmúködést a járvány elleni küzdelemben (Venkatraman, Manorahan 2021). Wuhanban az ineffektív kockázat-kommunikációért főként a kormányzat késői döntéshozatali folyamata és az információáramlás korlátozottsága, az információ inkoherenciája volt felelős. A kormányzatnak nem sikerült időben és a megfelelő módon megosztania a lakossággal a járvány eredményes kezeléséhez szükséges információkat. Ez hozzájárulhatott a járványfolyamat országos elterjedéséhez (Zhang et al. 2020).

A világjárvány idején azt tapasztaltuk, hogy az egészségügyi kommunikációt Magyarországon is erősen befolyásolta a média. Az információterjesztés csatornáinak jelentős átalakulásával párhuzamosan a szereplők új viselkedési formát választottak: az egészségügyi szakemberek médiaszereplőkké váltak, megváltoztatva a kommunikáció tartalmát és stílusát.

\subsection{A mediatizáció következményei: spektakularizáció és fragmentáció}

A spektakularizáció a látványosságra való törekevést, a fragmentáció a mondanivaló töredezettségét jelenti.

\section{Spektakularizáció}

A politikus üzenetét az adott médiumhoz kénytelen igazítani, a mondanivaló helyett a „látványosságra" törekszik. Mára fontosabb lett, hogy a politikus mondanivalóját hogyan adja át ahelyett, hogy mi is a beszédének tényleges üzenete. Michael Kunczik német médiakutató szerint: „a politika szórakoztatóiparrá degradálódik. A stílus fontosabb, mint a tartalom. A kampányban fontosabb a személyiség, mint a politikai gondolatok, különösen akkor, ha a gondolatok túlságosan összetettek, és így nem könnyü tudósítani róluk” (Kunczik 2001: 19, idézi BajomiLázár 2006: 99).

A spektakularizáció hatása Magyarországon az egészségügyi kommunikációban is tetten érhető. Elismert egészségügyi szakemberek váltak hirtelen médiaszereplőkké, és láthatóan kevésbé tudnak megbirkózni ezzel a feladattal, mint a politikusok. A szereplők magatartása megváltozott, és nehéz megítélni, hogy nyilatkozataikat mi is motiválja: „olyanok osztogatnak tanácsot, akiknek van fehér köpenyük, kutatói vagy orvosi címük - és a tudományétól eltérő motivációjuk. Anyagi érdekek, sértettség, mellőzöttség, politikai célok, termékeladás, praxisépítés, adatgyújtés - rengeteg tudományon kívüli motiváció lehetséges. ...Ne legyünk naivak: ezek a térítők legtöbbször tisztában vannak az általuk hirdetett tanok hamisságával, de nem a segítő szándék vezérli őket, akármennyire vonzó is számunkra, amit hallunk tőlük" (Hlacs 2020).

\section{Fragmentáció}

A médiahatás másik következménye, hogy a politikus mondanivalóját átalakítja, ezzel beszéde töredezett lesz, frappáns jelszavakat és rövid idézeteket kezd el alkalmazni. Ezt a szakirodalom a politikai diskurzus fragmentálódását előidéző hatásnak nevezi (Mazzoleni 2002) (Ezt a jelenséget a magyar miniszterelnök jóval korábban professzionális módon kezelte: „egyetlen dologgal törődjenek (...), hogy a tettek beszélnek... Ne figyeljenek oda arra, amit mondok, egyetlen dologra figyeljenek, amit csinálok")․․

És sajnos ugyanezt tapasztaljuk az egészségtudomány képviselőinél is. Megnyilvánulásaikban igyekeznek megfelelni a nyilvánosságnak, és ez számukra - akik szakmájukban a szakszavakhoz szoktak - az esetek többségében szinte megoldhatatlan feladatnak tünik: egyszerre kell megfelelniük a szakpolitikának, az állampolgároknak, és a különböző médiumok elvárásainak.

A fentiek következménye a következetes és világos, egyértelmü és hihető kommunikáció teljes hiánya. A politikusok és az egészségügyi szakemberek közötti véleménykülönbségek megjelenése a médiában tovább torzítja a tájékoztatás tartalmát, és ebben a káoszban az érintettek, a polgárok elbizonytalanodnak. A bizonytalanság a viselkedési szabályok figyelmen kívül hagyásában nyilvánulhat meg, ami akadályozhatja a járványok hatékony kezelését.

\footnotetext{
${ }^{1}$ https://hvg.hu/itthon/20110906_orban_wikileaks_ne_figyeljenek
} 


\subsection{A kommunikáció átfedései}

Mind a politikai (kormányzati), mind az egészségügyi kommunikációnak vannak olyan sajátosságai, amelyek önmagukban is megnehezítik a címzettek számára a mondanivaló értelmezését, és amikor ezek találkoznak, és együtt jelennek meg, a tisztánlátás, a világos üzenet, az érthetőség még bizonytalanabbá válik. Machiavelli szerint „háromféle emberi felfogás létezik: az egyik képes lesz arra, hogy önmagában felismerje a dolgokat, a másik azt teszi, amit a többiek felismernek, a harmadik pedig sem önmagában, sem mások által nem képes felismerni” (Machiavelli 1978: 76). E három érzékelés pedig egyenlőtlenül oszlik meg a közönségben.

A kommunikációs interakciók formái a COVID-19 idején megítélésünk szerint az alábbiak szerint alakulnak:

- a politika kommunikál a polgárokkal - gondoskodás, védelem, biztonság ígérete

- a politika kommunikál az egészségügyi szakemberekkel - utasítások kiadása/ellenőrzés

- polgárok - offline és online kommunikálnak egymással, a politikával és az egészségügyi szakemberekkel

Ha mindezt olyan körülmények között nézzük, amikor az üzenetküldők maguk sem biztosak abban, hogy mit mondanak, és a címzetteknek lehetőségük van arra, hogy ezt a vegyes információt egymás között értelmezzék - főként a médián és az online csatornákon keresztül -, akkor talán van értelme az általunk kidolgozott ábrának a COVID-19 körülmények közötti kommunikációval kapcsolatban (1.ábra).

Értelmezésünk szerint nálunk - de úgy tűnik más országokban is - a politika alapvetően meghatározza, hogy milyen információk jutnak el a szakemberekhez és az egyénekhez. A szakmai információk gyakran először politikai szűrő́n mennek át, majd a politikai irányítású médián keresztül jutnak el a címzetthez. Az egészségügyi kommunikáció is kettészakadt és - bár voltak átmenetek, „középen állók” -, alig maradt szakmailag hiteles egészségügyi megnyilvánulás. A politikához lojális vagy a politikai álláspontot elutasító egészségügyi szakemberek ellentmondásos kommunikációja összezavarhatja, megnehezítheti és torzíthatja a valós helyzet értelmezését az egyénekben.

1. ábra: Kik, mit, kinek és hogyan kommunikálnak?

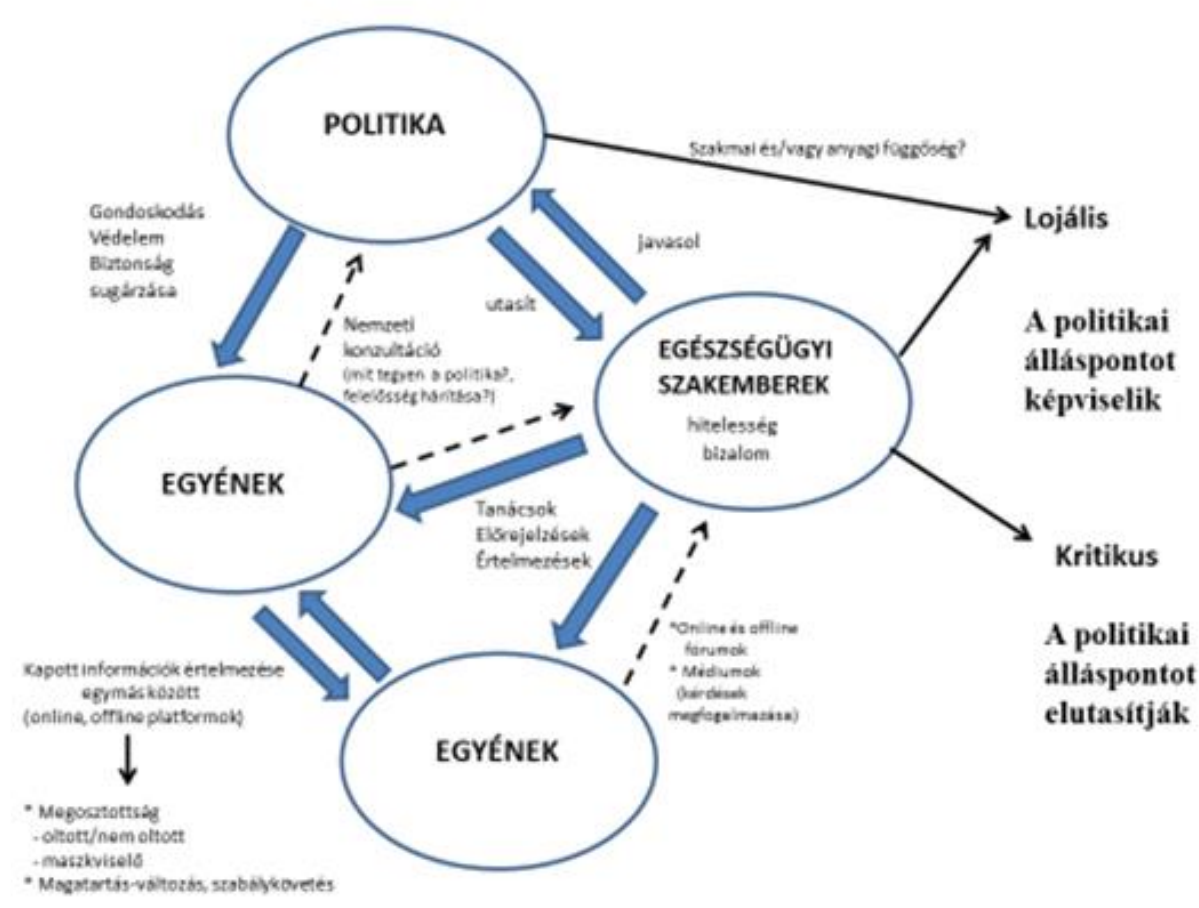

Forrás: Saját szerkesztés 


\section{Empirikus kutatás}

A COVID-19 Olaszországhoz, Spanyolországhoz, Ausztriához képest Magyarországon jóval később jelent meg, így a tanulságok levonására is lett volna idő. Az országban hozott politikai, egészségügyi és egyéb intézkedések azonban még több esetben megosztották a közvéleményt, amiben a politikai pártok hatalmi harcai is szerepet játszottak.

\subsection{A kutatási kérdések meghatározása}

Az egészségügyi kommunikáció problémáit vizsgálva már említettük, hogy az még normális körülmények között is hagy kívánnivalót maga után. Bár a betegeknek számos joguk van az információhoz, a kommunikációs csatornák, a kommunikáció módja és tartalma gyakran bizonytalanságot okoz. Ez a bizonytalanság még hangsúlyosabb lehet egy olyan kritikus helyzetben, mint amilyen a jelenlegi COVID-19 világjárvány, ahol a döntéshozók maguk sem biztosak abban, hogy mi a helyes út. A túlzó lépések és a következetlen információk összezavarják a címzetteket.

Kutatási problémánk az volt, hogy a mediatizált politikai és egészségügyi kommunikációban a bizonytalan tájékoztatás hogyan befolyásolja a polgárok véleményét? Hogyan terjednek a COVID-19-ról szóló ellentmondó, zavaros információk az interneten és különösen a közösségi médiában, és hogy viszonyulnak ezekhez a befogadók?

Kvalitatív kutatásunkban egy időszakot vizsgáltunk: a kutatási szakasz 2020 márciusa és 2020 májusa között történt, amikor a COVID-19 járvány kezelése kapcsán két kérdés volt napirenden Magyarországon: a maszkviselés és a kórházi ágyak gyors kiürítése annak érdekében, hogy a kórházak képesek legyenek a COVID-19 betegek befogadására.

Kutatási kérdéseink a következők voltak:

RQ1. Megkülönböztethetők-e speciális attitűdökkel rendelkező csoportok az arcmaszk viselésének szükségességéról szóló kommunikációval összefüggésben?

RQ2. Hogyan reagált a lakosság a kórházi ágyak kötelező kiürítéséről szóló kormányzati döntésre?

\subsection{Az elemzésbe bevonandó online kommunikációs formák meghatározása}

A netnográfia nagy előnye a kevésbé időigényes adatgyüjtés, az online forrásokból nyert adatok könnyebb elérhetősége, relevanciája, szélesebb köre, ellenőrizhetősége és heterogenitása (Kozinets 2010; Addeo et al. 2020). Az online platform számos lehetőséget kínál arra, hogy megtaláljuk a számunkra legmegfelelőbb kommunikációs formát. Kozinets (2002) azt ajánlotta, hogy az online közösségek kiválasztásakor több szempontot is vegyünk figyelembe. A közösség hozzájárulásának mértéke fontos a kutatási kérdések megválaszolásához: a hozzászólások gyakorisága, a hozzászólók száma, a részletesség szintje és az, hogy milyen gazdag a leírás, valamint a tagok között az interakció mértéke. Ezek lehetnek fórumok, blogok, azonnali üzenetküldők, közösségi hálózatok, közösségi oldalak, e-mail listák, játékfelületek. A kutatási problémák vizsgálatához online környezetből vettünk mintát, előnyben részesítve a vizsgálatunk szempontjából releváns, aktív és interaktív, heterogén és adatgazdag online közösségeket (Kozinets 2010).

Kutatásunkban politikailag vegyes online hírportálokat és egy hivatalos kormányzati portált vontunk be, és ezeken az online portálokon a kutatási kérdéseink szempontjából releváns hírekhez kapcsolódó fórumokat, Facebook bejegyzéseket vizsgáltuk. Az elemzés elvégzéséhez a következő magyarországi hírportálokat és azok Facebook-oldalait választottuk: www.index.hu, www.24.hu, www.hvg.hu, www.origo.hu, www.koronavirus.gov.hu. A vizsgált médiumok kiválasztását az 1. sz. ábrában bemutatott kommunikációs átfedések és a kutatási kérdések motiválták. A kommunikációs átfedések hatásának vizsgálatára a www.koronavirus.gov.hu tűnt alkalmasnak. Kutatási célunk az intézkedésekról kialakult lakossági vélemények klasztereinek megragadása volt, így nem a politikai beállítottságot, hanem az egyes hírportálok forgalmát, olvasottságát ${ }^{2}$, és a hozzászólások heterogenitását vettük figyelembe, amelyek lehetővé

\footnotetext{
2 https://thepitch.hu/legolvasottabb-hirportalok-hazai-weboldalak-listaja
} 
tették a különböző vélemény-kategóriák kialakítását. (A vizsgálatba bevont médiumok számát, illetve a kutatásunk tárgyához kapcsolódó, a vizsgálatba bevont híranyagok számát a terjedelmi korlátok is befolyásolták.) A választott portálokon elemzett híranyagokat, a melléklet tartalmazza (1. sz. melléklet).

\subsection{A részvétel szintjének meghatározása}

A vizsgált online közösség típusától, a kutatási céloktól és a kutatási terület jellemzőitől függően kétféle hozzáférést lehet megkülönböztetni (Addeo et al. 2020):

- rejtett hozzáférés (lurking) - a kutató anélkül figyeli a közösség kommunikációs tevékenységét, hogy a résztvevők tudnának a jelenlétéről és a kutatásról.

- nyílt hozzáférés (résztvevő megfigyelés) - a kutató tájékoztatja a közösség tagjait, és hozzájárulást kér tőlük. A résztvevő megfigyelés során a kutató jelenléte a vizsgált közösségben különböző szinteken és intenzitással valósulhat meg: linkek követése és olvasása, értékelés, kommentelés, válaszok írása a tagoknak, interjúkészítés e-mail formájában, aktív részvétel az online közösségi kommunikációban, egyfajta szakértői szerep (Morton 2001; Kozinets 2010).

Mi a passzív megfigyelés netnográfia módszerét alkalmaztuk, nem léptünk interakcióba a megfigyelt csoportokkal, nem reagáltunk és nem kommentáltunk semmilyen tartalmat, remélve, hogy ezzel az elemzés során az esetleges szubjektivitás is csökken.

\subsection{Adatgyújités}

A vizsgálathoz a Google keresőmotorját használtuk, a "maszk viselése", "maszk viselésének ajánlása", "kórházi ágy kiürítése" kereső kifejezések használatával kerestük a kutatásunk szempontjából releváns tartalmakat. Azokra az online hírportálokra összpontosítottunk, ahol a témával kapcsolatos bejegyzések voltak, és az olvasóknak lehetőségük volt a közösségi médiában/adott hírportálon kommentelni, és jelentős számú (legalább 300) hozzászólás érkezett. A tartalomelemzést a kutatási kérdéseink alapján végeztük.

\subsection{Az adatok elemzése, eredmények}

A külső megfigyelés lehetővé tette számunkra, hogy kövessük és megismerjük az online közösség értékeit, normáit és szerepeit, valamint tanulmányozzuk az online interakciók dinamikáját. A kulcsszavak segítségével kiválasztottunk néhány példát a hozzászólásokból, ezeket a kutatási kérdéseink alapján csoportosítottuk, majd a tartalomelemzés módszerével különböző véleménycsoportokat alakítottunk ki.

Az 5 hírportál 14 online fórumán összesen 2000 hozzászólás kapcsolódott a kutatási témánkhoz: 1422 a maszkviseléssel, 578 a kórházi ágyak kötelező kiürítésével kapcsolatban. Az arányok azt is jelzik, hogy ebben az első időszakban a lakosságot mely kérdések foglalkoztatták leginkább.

A kommentek feldolgozása során nem használtunk ismert softvereket (ATLAS.ti, MAXQDA NVivo). A „nagy hármas” a kétezres évektől a „mainstream”-et jelenti: olyan eljárások, amelyek lehetővé teszik a szövegszintű (kódolás) és a fogalmi szintű (hálózatépítő) munkát (Sántha 2017). A netnográfia alkalmazásakor azonban a kutató elsődleges technikája a tartalomelemzés, amely révén a kutatás alanyai által generált tartalmakat vizsgálja meg, azaz a tartalomelemzés szisztematikus, tudatos elemző eljárást jelent (Heidi 2008). A módszertani és technikai újítások kvalitatív elemzésekben történő megjelenése népszerü a nemzetközi szakirodalomban, de megfigyelhetők olyan törekvések is, amelyek a kvalitatív vizsgálatokban alkalmazható szoftverek használatával kapcsolatos elemzések minőségének vizsgálatára összpontosítanak (Niedbalski, Slezak 2016; Salmona, Kaczynski 2016).

A fentiek mérlegelése után a minőségi tartalomelemzést használtuk, amely alkalmas bármely dokumentum vagy szöveg elemzésére, hogy felfedje a rejtett mintákat (Gyulavári et al. 2014). A keresőszavakkal kiválasztott kommenteket szúkítettük, és kulcsszavakkal kerestük azokat a hozzászólásokat, amelyek érzelmekre, kompetenciákra, attitűdökre, stílusra utalhatnak. 
Esetünkben a tartalomelemzés során a viselkedésformákat, attitűdöket, tudásszintet, stílust és érzelmeket elemeztük, és ezek alapján alakítottuk ki a koordinátákra vonatkozó definíciókat eredményeink bemutatásakor.

Az egyes kategóriákhoz tartozó megjegyzésekből mutatunk be néhány példát.

Maszk viselése

Ami a maszk viselésének szükségességét illeti, a bejegyzések stílusa, hangulata és a posztolók hozzáállása alapján az online közösségen belül a résztvevők 4 kategóriáját azonosítottuk: Elfogadók/tanácsadók, Elégedetlenek és undorodók, Vádaskodók, Szkeptikusok (2. ábra).

A. Elfogadók/tanácsadók

A hivatalos kormányzati kommunikációtól függetlenül egyetértenek a maszk viselésével.

„Na végre! Ha nincs maszkotok, és nem kaptok, akkor készítsetek otthon, vagy viseljetek sálat. És a kesztyüről se felejtkezzetek el. Vigyázzatok magatokra, vigyázzunk egymásra."

„Ilyenkor mindenkinek úgy kellene viselkednie, mintha fertőzött lenne. A maszk pedig csökkenti a vírus továbbadásának esélyét.”

B. Elégedetlenek /felháborodottak

Zavarosnak, kaotikusnak tartják a kommunikációt, mivel országosan hiány van maszkokból.

„Inkább mondják azt, hogy nincs elegendő maszk, illetve nem is lesz. Ezért ami van azt hagyjuk meg az orvosoknak ( más lehetőség amúgy sincs ). A sok kamu szövegelés és állandó ködösítés már sok.”

„Itt az a gond, hogy nem nekem kellene maszkot vennem, hanem az államnak kéne adni. Vészhelyzetet hirdettek!!!!! Gondoskodni kéne a népről!!?? Inkább azt mondják nincs rá szükség....”

C. Vádlók

A kormányt és/vagy az Operatív Törzset okolják a zavaros kommunikációért és a következményes helyzetért.

„Müller Cecília egy báb, a kormánynak pedig-úgy túnik - nem a járvány a legnagyobb gondja. Egyébként azt gondolom, hogy kevés a maszk még most is, ezért találták ki ezt a "frappáns" megoldást."

„Azért hazudozza az állami propaganda, hogy nem kell maszk, mert eddig NEM VOLT! Egy hónapja kihirdették a világ-járványt, de mostanáig képtelenek voltak maszkokat beszerezni."

„Csak épp Müller Cecília és az Operatív Törzs mindenre IS alkalmatlan.”

\section{Szkeptikusok}

Ez a felhasználói csoport nem érti a maszk viselésének hasznosságát vagy nem ért egyet vele. Valószínúleg nem teljesen tájékozottak az arcmaszk helyes használatával és szerepével kapcsolatban. Hozzáállásuk semleges.

„A többség, aki hordja nincs tisztában azzal, hogy kell helyesen feltenni, viselni, majd levenni a maszkot."

„Ha csak a betegeknek kell hordani, mert nem véd meg a betegségtől, akkor az egészségügyi dolgozók miért hordják?" 
2. ábra: Vélemény-kategóriák: maszkviselés

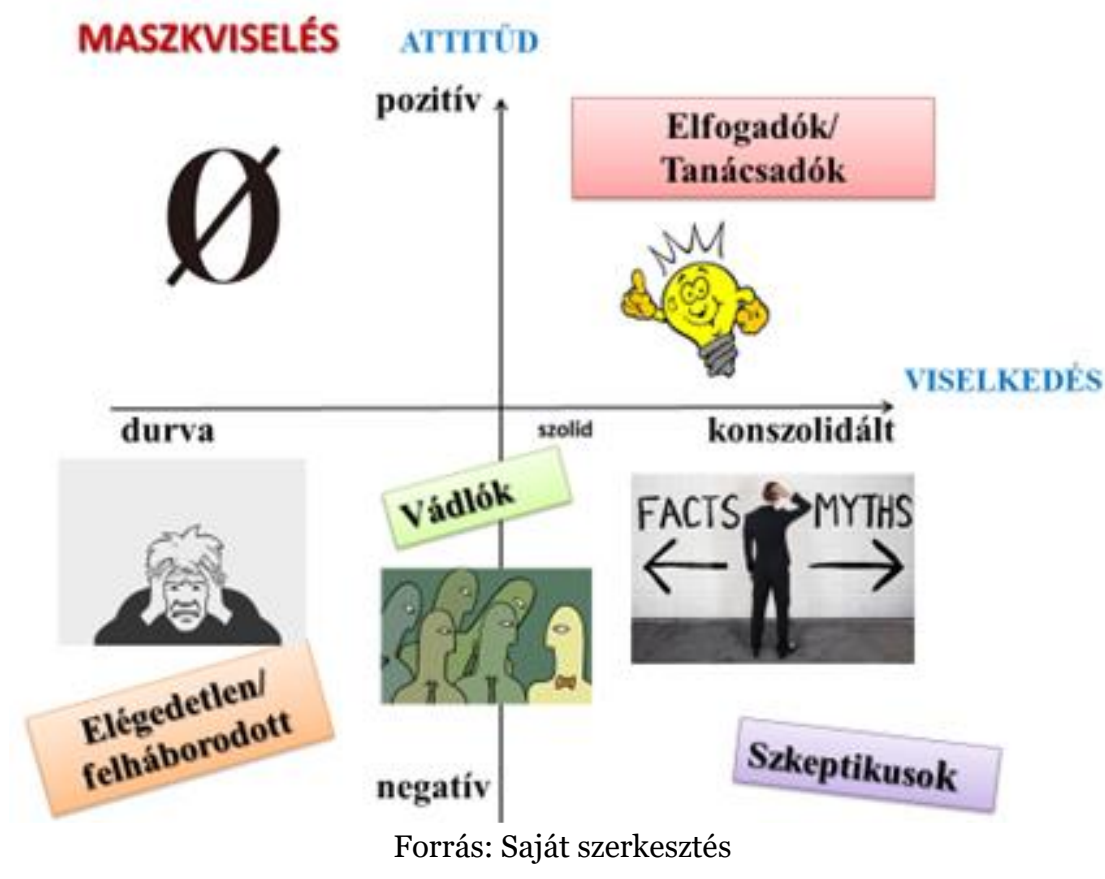

Kórházi ágyak kiürítése

A kórházi ágyak kiürítése kapcsán a hozzászólók attitűdje, a témával kapcsolatos kompetenciájuk alapján a résztvevők három kategóriáját határoztuk meg: Támogatók, Szkeptikusok, Felháborodottak (3. ábra).

\section{A. Szkeptikusok}

Nem igazán értik a kórházi ágyak kiürítésének okát, az attitüdjük inkább neutrális, dilletánsnak tünnek.

„Vegyék már észre, ez a döntés nem a vírusról szólt!!!!! Hanem az egészségügy átalakításáról és arról nem is beszélve, hogy az otthoni beteg után nem kell kórházi támogatást fizetni.”

„De nem lesz hirtelen több ezer beteg! Esetleg papíron, hogy a vészhelyzetet fenn tudják tartani és a tervüket megvalósíthassák. Ennyi.”

„Csendben jegyzem meg, esetleg külföldi betegeket hoznak?”

B. Felháborodottak

Erős érzelmi megnyilvánulás jellemző, aggódnak a betegekért, idősekért, családokért.

„Mivel fóként az idős, beteg emberekre veszélyes a vírus. 65 év felett mindenki maradjon otthon, a többiek pedig menjenek dolgozni! Hagyják már abba az ijesztgetést és az esztelen intézkedéseket!!!”

„Koronavírusos fertőzőbetegeket küldenek haza előzetes értesítés nélkül a családjukhoz. Magatehetetlen, állandó orvosi felügyeletet igénylő embereket olyan körülmények közé, hogy biztosan meghaljanak."

C. Támogatók

A kórházi ágyak kiürítését bizonyos mértékig szükségesnek tartják, a többieket érvekkel próbálják meggyőzni. 
„Nem gondolsz bele abba, hogy ha több ezren lesznek hirtelen betegek? Nekik kell az ellátás.”

„Az ápolás igénylő nem azonos a kórházi ápolás igénylővel. A kórházak helyett megfelelő más ellátási rendszer kellene, és megfelelő szociális ellátás!

Pl. az "elfekvő", és más szociális alapon kórházban fekvőnek más ellátási forma kell, ami nem az egészségügyi rendszert terheli!"

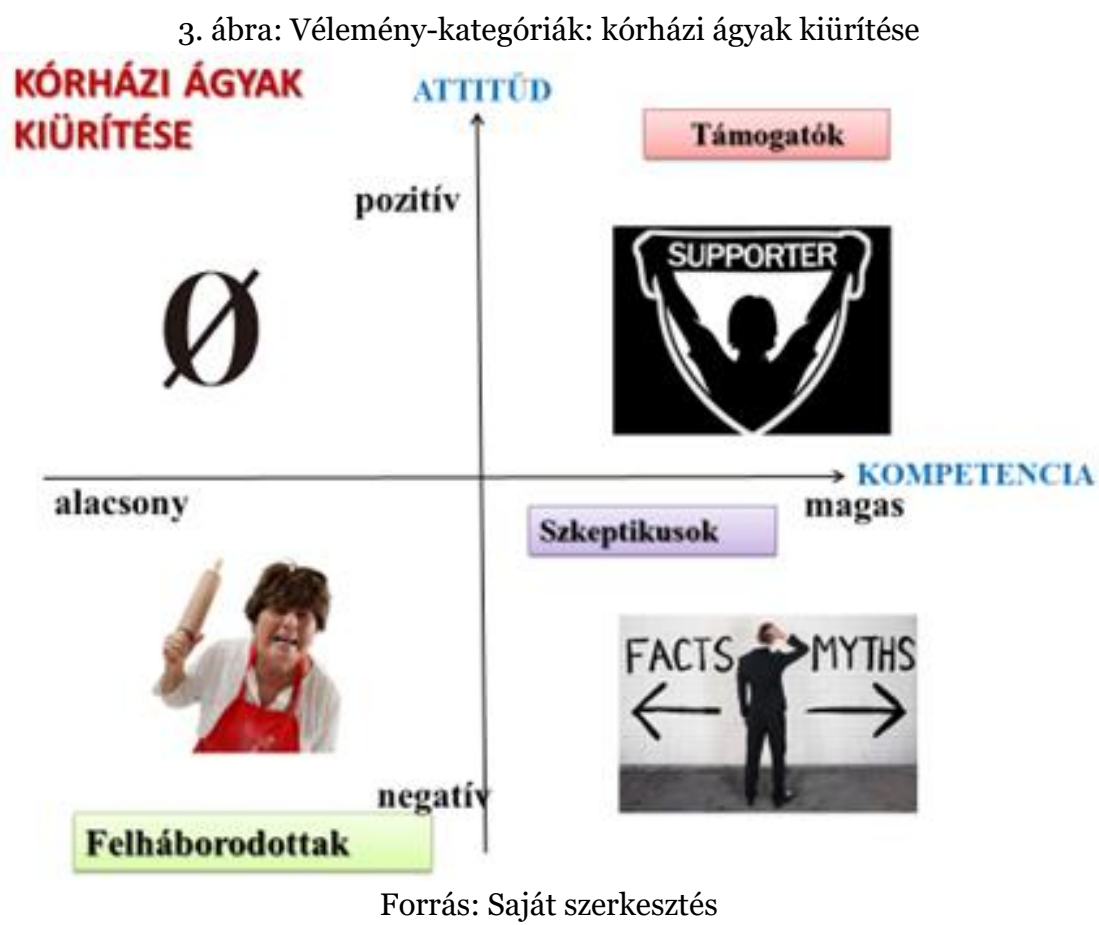

\section{Összegzés}

Az eredmények alapján arra a következtetésre jutottunk, hogy a hazai pandémia első szakaszában a vizsgált két neuralgikus téma megosztotta az állampolgárok véleményét. A maszkviselés kommunikációja és a kórházi ágyak kiürítése jelentősen eltérő véleménycsoportokat alakított ki, és ezek az eredmények azt jelzik, hogy a hatékonynak minősített COVID-19-járványkezelés ellenére nagyon szélsőséges vélemények jelentek meg a vizsgált online platformokon a társadalomban az egészségügyi és politikai kommunikáció pontosságáról és megbízhatóságáról. A túlzott és meggondolatlan megelőző lépések, amelyekből néha hiányoztak a szakmai és tudományos alapok, és a politikailag uralt, rendezetlen kommunikáció befolyásolhatta a lakosság bizalmát.

A kvalitatív kutatás jelzi, hogy a közegészségügyi válság kezelése a döntések mélyebb előkészítését és a döntéshozók következetes kommunikációját igényelte volna. Feltételezzük, hogy a járvány negatív társadalmi következményei meghaladhatják a magyarországi közvetlen egészségügyi károkat. A politika által befolyásolt egészségügyi kommunikáció ellentmondásossá válhat, ezáltal akadályozva a járvány hatékony ellenőrzését. Ennek jelei észrevehetők a szakértôk és a nyilvánosság közötti kommunikációban. Kutatásainkat a harmadik hullámban is folytattuk az oltási tervvel kapcsolatos vélemények vizsgálatával, ám miután ez a folyamat még tart, így annak részeredményeit ebben a tanulmányban nem mutattuk be.

Természetesen nem állítjuk, hogy ez a korlátoktól nem mentes kutatás általános következtetésekre alkalmas lehet. Kutatásunkat korlátozta az idő rövidsége, a vizsgált platformok heterogenitása és a járvány berobbanásának idején tapasztalható bizonytalan körülmények. Sőt, mi sem maradhattunk teljesen objektívek ebben a helyzetben. A jövőben további minőségi és 
mennyiségi vizsgálatokra van szükség világszerte a COVID-19 világjárvány társadalmakra gyakorolt átfogó hatásainak vizsgálatához. Eredményeink talán inspirálhatják és támogathatják ezeket a megközelítéseket.

Eddigi eredményeink alapján azonban úgy gondoljuk, hogy azok a tendenciák, amelyek Magyarországon a politika és a tudomány szimbiózisához vezetnek, nem lehetnek hosszútávon hatékonyak. Ez az összefonódás korábban sokkal inkább jelen volt a politika területét felölelő társadalomtudományokban (pl. szociológia), amikor azonban a természettudomány területén is megjelenik, az már aggodalomra ad okot. A tudományok - jelen esetben az egészségtudomány - korrumpálódása beleáthatatlan következményekkel járhat. Az is nyilvánvaló, hogy ez a folyamat nem hazai jelenség, ezt a szakirodalmi áttekintésünk is igazolja, és ez a folyamat így még drámaibb. A nagy kérdés az, hogy a politika érdekei által vezérelt - nem autonóm - tudomány sorsa mi lesz a jövőben?

\section{Irodalom}

Addeo, F., Paoli, A. D., Esposito, M., Bolcato, M. Y. (2020). Doing social research on online communities: The benefits of netnography. Athens Journal of Social Sciences, 7(1), 9-38.

Arisztotelész (1994). Politika. Gondolat Kiadó.

Aronson, E. (1972). The social animal. Viking Press.

Athique, A. (2020). Extraordinary issue: Coronavirus, crisis and communication. Media International Australia, 177(1), 3-11. https://doi.org/10.1177/1329878X20960300

Bajomi-Lázár P. (2005). A politika mediatizációja és a média politizálódása. Médiakutató. 1. tavasz https://mediakutato.hu/cikk/2005_01_tavasz/03_politika_mediatizalodasa/. Utolsó letöltés: 2021. 08. 05.

Bihari M. (2013). A politika és a modern állam. Pártok és ideológiák. Nemzedékek Tudása Tankönyvkiadó Zrt.

Breton, P. (2000). A manipulált beszéd. Helikon Kiadó.

Christensen, C. L. (2016). The mediatization of health expertise: Health programmes on Danish public service television. Critical Studies in Television: The International Journl of Television Studies. 11(2), 204-216. https://doi.org/10.1177/1749602016645771

Csepeli Gy. (2010). Politikai antropológiai előadások 12. Társadalmi Konfliktusok Kutatóközpont. http://konfliktuskutato.hu/index.php?option=com_content\&view=article\&id=252:12-apolitikai-kommunikacio\&root=239\&catid=23:fejezetek

Grice, H. P. (1997). A társalgás logikája. In: Pléh Cs., Siklaki I., Terestyéni T. (szerk.). Nyelv Kommunikáció - Cselekvés. Osiris. 213-227.

Gyulavári T., Mitev A., Neulinger Á., Neumann-Bódi E., Simon J., Szűcs K. (2014). A marketingkutatás alapjai [The basics of marketing research]. Akadémiai Kiadó, Budapest

Hanafiah, M. K., Ng, C., Wan, A. M. (2021). Effective Communication at Different Phases of COVID-19 Prevention: Roles, Enablers and Barriers. Viruses, 13, 1058. https://doi.org/10.3390/v13061058

Heidi, J. (2008). Conent analysis. In: Given, L. M. (2008). The Sage Encyclopedia of Qualitative Research Methods, vol. 1-2. Los Angeles: SAGE

Hlacs E. (2020). Kiáltvány a járvány közepén: több türelmet a tudománynak! Válasz Online. https://www.valaszonline.hu/2020/11/16/tudomany-koronavirus-hlacs-emese-publi/. Utolsó letöltés: 2020. 11. 16.

Kata, Anna (2012) Anti-vaccine activists, Web 2.0, and the postmodern paradigm - An overview of tactics and tropes used online by the anti-vaccination movement. Vaccine $303778-3789$. https://doi.org/10.1016/j.vaccine. Utolsó letöltés: 2011. 11. 12.

Komár Z. (2019). Meggyőző és manipulatív befolyásolási stratégiák a reklámretorika szemszögéből: szalmabáb, hamis dilemma, személyeskedés és egyéb reto-logikai érvelési hibák tettenér(t)ése. In: Csordás T., Varga Á. (szerk.). DMMD adapter - Tanulmányok a digitális marketing, média és design területéről. Budapesti Corvinus Egyetem. 75-96.

Kunczik M. (2001). A demokratikus újságírás. Médiakutató. 2. nyár https://mediakutato.hu/cikk/2001_02_nyar/01_demokratikus_ujsagiras. Utolsó letöltés: 2021. 04. 15.

Leão, T., Amorim, M., Fraga, S., Barros, H. (2021). What doubts, concerns and fears about COVID-19 emerged during the first wave of the pandemic? Patient education and counseling, 104(2), 235-241. https://doi.org/10.1016/j.pec.2020.11.002

Lippmann, W. (2007). A külvilág elménkben. In: Angelusz R., Tardos R., Tersényi T. (szerk.). Média Nyilvánosság - Közvélemény. Gondolat Kiadó. 95-104.

Locke, J. (1986). Értekezés a polgári kormányzatról. Gondolat Kiadó.

Machiavelli, N. (1978). A fejedelem. Európa Kiadó. 
Malik, M.A., Khan, L., Quan-Haase, A. (2021). Public health agencies outreach through Instagram during the COVID-19 pandemic: Crisis and Emergency Risk Communication perspective. International Journal of Disaster Risk Reduction, 61, 102346.

Mazzetti, M. (2020), COVID-19, political communication, and public health: A Transactional Analysis perspective. Psychotherapy and Politics International,18, e1562. https://doi.org/10.1002/ppi.1562

Mazzoleni, G., Schulz, W. (2002). A politika „mediatizációja”: kihívás a demokrácia ellen? Politikatudományi Szemle., 11(1-2), 135-156.

Mazzoleni, G. (2002). Politikai kommunikáció. Osiris Kiadó.

McFadden, S. A., Malik, A. A., Aguolu, O. G., Willebrand, K. S., Omer, S. B. (2020). Perceptions of US population regarding the novel coronavirus outbreak. PloS One, 15(4), e0231808.

Merkovity N. (2008). Politikai kommunikáció és politikai marketing. Politikatudományi Szemle, 17(4), 77-102.

Nazir, M., Hussain, I., Tian J., Akram, S., Mangenda Tshiaba, S., Mushtaq, S., Shad, MA. (2020). A Multidimensional Model of Public Health Approaches Against COVID-19. International Journal of Environmental Research and Public Health, 17(11): 3780. doi: 10.3390/ijerph17113780

Niedbalski, J., Ślęzak, I. (2016). Computer Analysis of Qualitative Data in Literature and Research Performed by Polish Sociologists. Forum Qualitative Sozialforschung / Forum Qualitative Social Research, Vol. 17 No. 3. https://doi.org/o.17169/fqs17.3.2477

Rozina, G., Karapetjana, I. (2009). The Use of Language in Political Rhetoric: Linguistic Manipulation. SDÜ Fen Edebiyat Fakültesi Sosyal Bilimler Dergisi Mayıs, 19, 111-122.

Salmona, M., Kaczynski, D. (2016). Don't Blame the Software: Using Qualitative Data Analysis Software Successfully in Doctoral Research. Forum Qualitative Sozialforschung/Forum Qualitative Social Research Vol. 17 No. 3. http://nbnresolving.de/urn:nbn:de:0114fqs1603117. Utolsó letöltés: 2021. 08. 05.

Sántha K. (2017). Számítógéppel támogatott kvalitatív adatelemzés a hazai neveléstudományi PhDképzésben. Képzés és gyakorlat, 15 1-2. 159-173. https://doi.org/10.17165/TP.2017.1-2.9

Schmitt, C. (1935). Die Verfassung der Freiheit. Deutschen Juristen-Zeitung, 40, 1133-1135.

Smailhodzic, E., Hooijsma, W., Boonstra, A., Langley, D. (2016). Social media use in healthcare: A systematic review of effects on their relationship with healthcare professionals. BMC Health Services Research, 16(1), 442.

Strömbäck, J. (2008). Four Phases of Mediatization: An Analysis of the Mediatization of Politics. The International Journal of Press/Politics, 13(3): 228-246.

Szczepanski, J. (1973). A szociológia története. Kossuth Könyvkiadó.

Wright, K., Sparks, L., O'Hair, H. D. (2013). Health Communication in the 21st Century. 2 d ed. London: Blackwell.

Venkatraman, K., Manoharan, A. (2021). Public Engagement as the Fifth Dimension of Outbreak Communication: Public's Perceptions of Public Health Communication during COVID-19 in India. Health communication, 1-13. https://doi.org/10.1080/10410236.2021.1950294

WHO (2017). WHO Strategic Communications Framework for effective communications. https://www.who.int/mediacentre/communication-framework.pdf. Utolsó letöltés: 2021. 08. 05.

Zhang, L., Li, H., Chen, K. (2020). Effective risk communications for public health emergency: Reflection on the COVID-19 (2019-nCOV) outbreak in Wuhan, China. Healthcare, 8(1), 64.

\section{1. sz. melléklet: Az elemzéshez felhasznált néhány hírportál és híranyag}

Maszkviselés:

https://index.hu/techtud/2020/04/22/eros_ervek_szolnak_a_teljes_koru_maszkviseles_mellett/

https://koronavirus.gov.hu/cikkek/amit-szajmaszk-viseleserol-tudni-kell

https://www.origo.hu/itthon/20200428-mindenkinek-kotelezove-tehetik-a-szajmaszkot-aboltokban.html

https://hvg.hu/tudomany/20200520_koronavirus_arcmaszk_viselese_alhir_snopes

https://24.hu/kozelet/2020/o3/26/muller-cecilia-ha-nem-vagyunk-betegek-a-maszk-viselese-megkaros-is-lehet/

\section{Ágyfelszabadítás:}

https://www.facebook.com/koronavirus.gov.hu/posts/131003975176499

https://24.hu/fn/gazdasag/2020/04/16/koronavirus-magyarorszag-korhazi-agy-felszabaditas/

https://index.hu/belfold/2020/05/20/kasler_interju_demokrata_korhazkiurites_koronavirus_jarvan y_emmi_miniszter/

https://www.origo.hu/itthon/20200415-korhaz-koronavirus-egeszsegugy.html

https://hvg.hu/itthon/20200414_koronavirus_korhaz_ferohely_agyszam_kronikus_beteg_otthon_a polas 